\title{
Looking for paint mixtures to glimpse pictorial techniques: a micro-stratigraphic physicochemical approach to the rock art from the Oyola's Caves (Argentina)
}

\author{
Lucas Gheco ${ }^{1,2^{*}} \mathbb{D}$, Marcos Tascon ${ }^{1,3}$, Eugenia Ahets Etcheberry ${ }^{1}$, Marcos Quesada $^{2,4}$ and Fernando Marte ${ }^{1}$
}

\begin{abstract}
Could not be possible that rock paintings with similar hues and morphologies were the result of different paint preparations inside a cave but distanced in time? Is there any archaeometric approach that allow us to evidence these subtle differences? Aiming to address these inquires, in this work are presented the potentials of new physicochemical lines of evidence for characterization and differentiation of paint mixtures. This will improve the understanding of the technical heterogeneity and temporal complexity of painting sets executed in a particular archaeological site. In order to explore these points, the results obtained in the micro-stratigraphic studies of samples taken from the painted walls of Oyola, an archaeological site located in the northwest of Argentina, are presented. These samples have been analyzed by micro-Raman spectroscopy (mRS) and scanning electron microscopy with energy dispersive X-ray (SEMEDS). The differences found by cross-section chemical studies could be explained as a consequence of two situations: 1-differences in the painting's chemical components, either in the pigments involved or additives used; and, 2-differences in the physical properties of the mixtures such as stratum thickness and/or particle size. Also, in this article are explained each of the hypothesis, presenting the limits of these interpretations and pointing out future research challenges. As we discussed, it could be possible that the chemical and physical differences found between paint mixtures were the material expression of varied types of pictorial techniques.
\end{abstract}

Keywords: Rock art, Archaeology, Archaeometry, Painting techniques

\section{Introduction}

In last decades, archaeometric studies have been a powerful tool to understand the materials employed in paintings [1-6] as well as the natural and/or anthropic phenomena that affect them throughout time [7-12]. Also, direct absolute chronology of paintings has demonstrated to be a powerful tool in this matter $[13,14]$. However, the potential of physicochemical studies has not been completely exploited and there are great

\footnotetext{
*Correspondence: gheco@hotmail.com

${ }^{1}$ Instituto de Investigaciones Sobre el Patrimonio Cultural (IIPC-TAREA), Universidad Nacional de San Martín, Benito Quinquela Martín 1784, Buenos Aires, Argentina

Full list of author information is available at the end of the article
}

possibilities to contribute to the actual discussions about historical processes and social practices that constructed and modified rock painting sites. The research of diachronic processes of production and transformation of rock art panels is a worldwide problem that raises intriguing challenges to approach the elucidation and identification of different painting events [6, 15-19].

As a matter of fact, a painting is the result of the application of different paint mixtures with determined proportions of diverse materials onto the rock surface using specific tool/s and technique/s. These mixtures have been usually described in the literature as the combination of a pigment (grounded solid colored materials or organic colorants), a binder (commonly an organic material) and
Springer Open

(c) The Author(s) 2020. This article is licensed under a Creative Commons Attribution 4.0 International License, which permits use, sharing adaptation, distribution and reproduction in any medium or format, as long as you give appropriate credit to the original author(s) and the source, provide a link to the Creative Commons licence, and indicate if changes were made. The images or other third party material in this article are included in the article's Creative Commons licence, unless indicated otherwise in a credit line to the material. If material is not included in the article's Creative Commons licence and your intended use is not permitted by statutory regulation or exceeds the permitted use, you will need to obtain permission directly from the copyright holder. To view a copy of this licence, visit http://creativeco mmons.org/licenses/by/4.0/. The Creative Commons Public Domain Dedication waiver (http://creativecommons.org/publicdomain/ zero/1.0/) applies to the data made available in this article, unless otherwise stated in a credit line to the data. 
additives (regularly used as extenders, fillers or charges) [7, 12, 20-31]. The pigments, also known as chromophores, are the responsible to give color to the painting. Most of the archaeological literature has reported iron oxides to obtain red and yellow, calcium carbonate and calcium sulphate for white colors, and carbon or manganese oxide compounds for black hues [6,32, 33]. Then, the binders give cohesion to the mixture and have been linked to organic compounds, as animal fat or vegetable oils [34, 35]. Gypsum, clays, quartz, bone and talc have been described as additives and usually are employed to give volume and/or to improve other paint properties such as adherence, coverage and durability [28]. However, the paintings are not only the sum of materials, but also the product of various preparation stages, practices and physical transformations employed to obtain desired final painting properties such as color hue, brightness, durability, texture, etc. Such activities could be grinding, sifting, mixing, heating treatments, among others [36-40]. Therefore, these combinations of activities and materials produce mixtures that are chemically and/or physically different from other preparations, even if same raw materials have been originally employed. Each of these material mixtures could be defined as a paint mixture. This concept is not equivalent to the recipe's notion, because involves the result of a particular paint preparation different from others following the same general rule.

The minimum execution unit involved in rock art's production could be defined as a painting act. This notion comprises the episode of interaction among an agent, one paint mixture and a rock support, and could be associated with a minimal artistic unit, usually called "simple motif" to describe a monochrome figure [41]. Multiple and relatively contemporaneous painting acts performed inside a cave or shelter conform a painting event. This concept includes one or more agents and could be associated to several paint mixtures. Nevertheless, we believe that one mixture per color was performed in the same painting event. Thus, different paint mixtures of similar colors detected inside a cave could be the expression of various painting events chronologically distanced. Although this proposal must not be understood as a deterministic relation, we thought that the identification of different paint mixtures could be a valuable hint to reach, in combination with other lines of evidences, the historical development of rock art panels.

Notwithstanding, the material differences between painting events sometimes remain eclipsed behind the uniformity appearance of painting sets with similar morphologies and colors, promoting synchronic interpretations of rock art that misunderstand the site's history. Could not be possible that paintings with similar hues and designs were the results of different paint preparations distanced in time? Is there any archaeometric approach that allows us to evidence these subtle differences? Aiming to address these inquires, in this work the potentials of novel physicochemical lines of evidence for characterization and differentiation of paint mixtures are presented. In this sense, the results obtained in the micro-stratigraphic studies of samples taken from the painted walls of Oyola, an archaeological site situated in the northwest of Argentina, are gathered. These samples have been analyzed by micro-Raman spectroscopy (mRS) and scanning electron microscopy with energy dispersive X-ray (SEM-EDS). Particularly, new variables and levels of understanding have been defined for paint mixtures characterization; namely, differences in pigments and additives, and differences in materials preparation. These results will improve not only the understanding of the technical heterogeneity and temporal complexity of painting sets in Oyola but also could be a useful methodological alternative to apply in other archaeological sites. Finally, it must be highlighted that this study is the result of a large number of samples collected and analyzed from the archeological site of Oyola for the last 7 years $[12,18$, $27,42]$.

\section{The archaeological site of Oyola}

At the eastern side of El Alto-Ancasti's mountain, Catamarca province preserves one of the most outstanding groups of rock art sites in South America. Having more than a hundred caves documented, these paintings and engravings stand out by their diversity, colors, sizes and good preservation. After some decades of studies, most of the researchers attribute the rock art of this area to the La Aguada culture, chronologically located between 600900 a.C. [43-46]. This cultural adscription rest on stylistic similarities detected between some rock art figures and the iconographic repertoire of La Aguada embodied in pottery vessels. The traditional interpretation of this period describes a social integration between different groups as a consequence of a shared ideology materialized in a common repertory of designs in pottery, lithic objects and rock art motifs [47, 48]. Figures of shamans, warriors, trophy heads and jaguars characterized this culture and expressed a powerful religious ideology that links and joints communities with different historical developments.

The archaeological site of Oyola is located in the middle of the eastern hillside of El Alto-Ancasti's mountain, approximately at 700 meters above sea level (Fig. 1). It is shaped by 38 rock shelters with prehispanic paintings and/or engravings executed in the roof and walls of granitic caves, with a diversity of color hues, morphologies, sizes and spatial arrangements. The last survey of the shelters allows us to identify more than 350 motifs, 


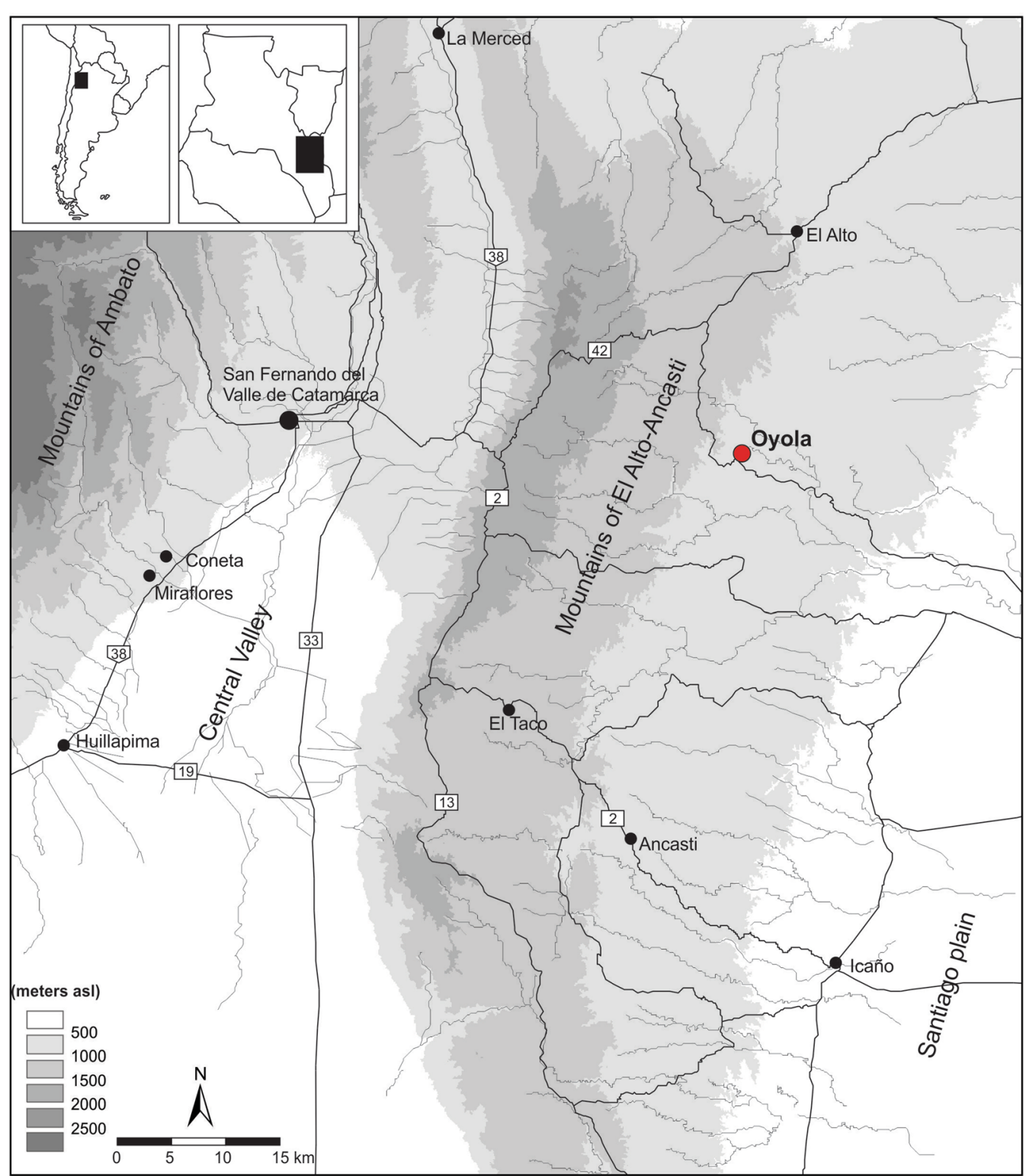

Fig. 1 Map of El Alto-Ancasti's mountain with the localization of Oyola's archaeological site

with the predominance of abstract designs and, among the figuratives, camelids and anthropomorphic motifs. The firsts researches at Oyola were carried out in the 1970s by Amalia Gramajo and Hugo Martínez Moreno $[49,50]$. As a consequence of this initial documentation, the authors claimed that the rock art of Oyola could be linked with La Aguada culture. Later, other researchers supported this interpretation and reinforced the uniform cultural adscription to one culture and temporal period [46]. However, they also described some motifs that could not be stylistically attributed to
La Aguada arising hypothesis regarding the presence of other groups before and/or after this culture.

In this context, the hypothesis of a wider chronology is considered, focusing our studies on the application of different lines of evidence to approach the histories of production and transformation of rock art panels. In this way, we have performed stratigraphic excavations of the caves [51], stylistic studies of paintings [52], analysis of overlapping figures [53], spatial studies of the places selected to do the paints [52] and chemical analysis of micro-samples taken from paintings [12, 18, 42]. By the 
development of strategies to link all these evidences [18], the research group was able to reach a more complex understanding of the site's history, with paintings attributed to La Aguada culture but others linked with prior and later occupation periods. In this regard, the chemical analyses of micro-stratigraphic samples were a valuable tool to differentiate sets of paintings with similar color hues, morphologies and styles, usually interpreted as chronological equivalent and attributed to La Aguada culture.

This homogenous first appearance characterizes the rock art repertories of many caves at the site, such as Oyola 1, Oyola 7 and Oyola 34. These caves share the same archaeological problem: at a first glance, the painted panels look uniform with paintings of similar colors, forms and without overlapping. However, as we explain in this article, evidences contradicting this preliminary interpretation were detected in most of the caves. These differences were found by cross-section chemical study of samples taken from the figures and could be explained as a consequence of, at least, two situations: 1-differences in the chemical components, either in the pigments or additives used; and, 2-differences in the physical properties of the mixtures. In the next section we explain each hypothesis, present the limits of these interpretations and describe future research challenges. As we discuss below, it could be possible that the chemical and physical differences found between paint mixtures were the material expression of varied types of pictorial techniques.

\section{Materials and methods}

The methodological strategy followed in this research is based on the study of micro-stratigraphic samples of some rock paintings combined with a layer-by-layer chemical and morphological characterization studies. The samples were taken from specific rock art panels in caves Oyola 1, 7 and 34 (Table 1).

The method used for the micro-stratigraphic analyses involves a sequence of stages before, during and after sampling, the detailed information can be found elsewhere [12, 42]. Briefly, the samples (of about $1 \mathrm{~mm}^{2}$ ) were taken using a scalpel and binocular lenses (OptiVISOR, Donegan Optical Company, USA) for deeper precision, being afterwards stored in 1.5-mL-capacity Eppendorf tubes. Then, each sample was included in acrylic resin $\left(\right.$ Subiton $\left.^{\circledR}\right)$ and was polished with sandpaper of different granulometry in order to expose its cross section. Finally, a DM EP model MC 170 HD Leica microscope (Leica, Germany) was used to observe and photograph the samples. Visible light source was used in normal and polarized modes for further documentation. Images were recorded using a Leica DFC280 digital camera and processed using the Leica Application Suite 4.0 software.
Table 1 Samples taken for physicochemical analyses from caves Oyola 1, 7 and 34

\begin{tabular}{llll}
\hline Sample & Rockshelter & Colour & Type of motif \\
\hline 329-1-17 & Oyola 1 & Black & Bird \\
329-1-18 & Oyola 1 & Black & Camelid \\
329-07-02 & Oyola 7 & Red & Feline \\
329-07-03 & Oyola 7 & White & Geometric \\
329-07-14 & Oyola 7 & White & Bird \\
329-07-30 & Oyola 7 & Red & Anthropomorphic \\
329-34-1 & Oyola 34 & Black & Camelid \\
329-34-3 & Oyola 34 & Red & Camelid \\
329-34-13 & Oyola 34 & Black & Camelid \\
329-34-14 & Oyola 34 & Red & Camelid \\
\hline
\end{tabular}

Regarding chemical characterization of paintings, two complementary techniques were used. First, elemental inorganic studies were performed using scanning electron microscopy with Energy-dispersive X-ray spectroscopy (SEM-EDS) Philips SEM 505 (Philips Industries, Eindhoven, NL). All samples were metalized with gold. Micrographs, elemental mappings, and EDS spectra were acquired. Second, for molecular inorganic characterization, the samples were analyzed by micro-Raman spectroscopy using a Lab RAM HR UV-Vis-NIR (Horiba Jobin-Yvon) spectrograph equipped with two monochromator gratings and a charge-coupled device detector. A grating of $1800 \mathrm{~g} / \mathrm{mm}$ and a hole of $100 \mathrm{~mm}$ resulted in a spectral resolution of $1.5 \mathrm{~cm}^{-1}$. The spectrograph was coupled to a microscope with $\times 10, \times 50$, and $\times 100$ magnification lenses. Laser lines at $514 \mathrm{~nm}(\mathrm{Ar}+$ laser$)$ and at $623 \mathrm{~nm}$ were used as the excitation sources and filtered to ensure the power density was low enough to avoid sample overheating. Typically, for a $\times 50$ magnification, spot diameter was about $2-3 \mu \mathrm{m}$.

The physical analyses of samples were done by measurements of stratum thickness and particle area under microscope observation. The software employed for this was LAS (Leica Application Suite) Versión 4.0. (Build: 878) from Leica Microsystems. These analyses were developed in those samples that, although its chemical similarities, presented morphological differences.

\section{Results}

\section{Chemical differences between paint mixtures Pigments}

The cave Oyola 34 presents fourty zoomorphic figures representing camelids painted with red, black and white colors. The first appearance of these panels could be understood as a result of a single painting event, perhaps the representation of a caravan scene due to the lineal arrangement of motifs with similar morphology (Fig. 2). 


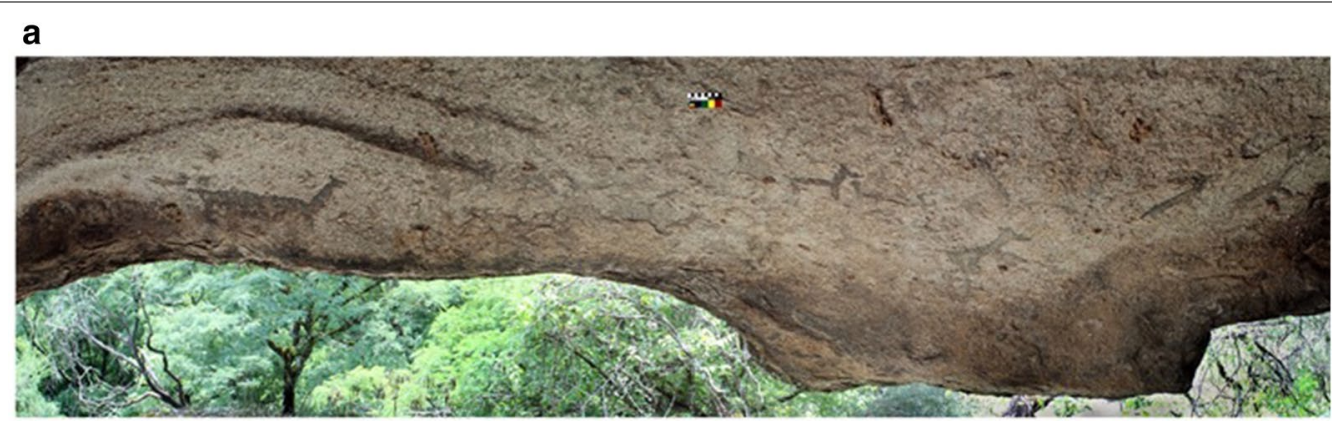

b

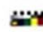

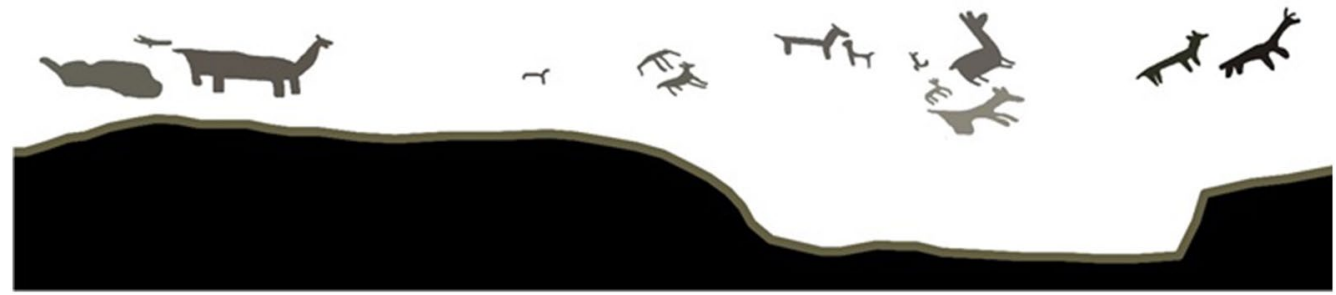

Fig. 2 a Photograph of rock art panel at cave Oyola 34, and $\mathbf{b}$ digital tracing of figures

However, the chemical analysis of the cross-sections taken from different figures of this panel allowed us to discern the apparent employment of different pigments. Noteworthy, these pigments were used in such a way that creates similar color hues. In Fig. 3 are shown the samples taken from two different camelids that, at a first glance, seem to be part of the same painting event. SEMEDS mapping analyses shown, on one hand, for sample 329-34-13 the presence of manganese in the painting layer while; on the other hand, for sample 329-34-1 substantial concentration of sulphur and calcium in the black stratum, without signals of manganese. Furthermore, Raman spectra of painting layers evidenced the presence of gypsum in both type of samples where the characteristic bands at 1007, 1032 and $415 \mathrm{~cm}^{-1}$ were found [12] (Fig. 4). These results indicate the use of two different pigmentary mixtures; one employing a manganese-based pigment while the other could be a carbon-based one. This latter hypothesis is supported in the discovery of black paintings at Oyola with carbon pigments $[52,54]$.

Also, from an archaeological point of view, these results describe heterogeneity of paint mixtures used to create similar figures in the same pictorial composition. This behavior was not an isolated event, but similar trends were found in other caves of the same site (Table 2). For instance, this is also the case of Oyola 7 [27], which presents several white paintings on the walls that could be also interpreted as the product of a single paint mixture. However, the chemical analyses of different samples have demonstrated different compounds as the main pigment.
For instance, in Fig. 5a can be evidenced the presence of calcite where the characteristic Raman bands at 1087, 282 and $156 \mathrm{~cm}^{-1}$ [55] are indicated. On the other hand, compositional studies of other white motifs from the panel showed the exclusive presence of gypsum as the main pigment without calcite. As an example, in Fig. 5b is presented the Raman spectrum from one of the motifs where the characteristic bands of gypsum $\left(\mathrm{CaSO}_{4}\right)$ are evidenced $[12,55]$. Besides, these results could be linked with the use of two different white pigments and allow us to take under consideration the existence of more than one painting event in the cave's history.

\section{Additives}

Materials that are usually added to paint mixtures in order to obtain particular color hues, increase the adherence, volume or resistance are commonly known as additives [56]. This category includes a wide range of components documented in rock art, such as gypsum, quartz, feldspar, talc, clays, among others [28, 29]. In the case of Oyola, these materials have been detected through the micro-stratigraphic studies of some paintings.

For example, the red figures of camelids placed in the walls of Oyola 34. Although, they present similar morphologies and colors (Fig. 6), the chemical analysis gives us valuable information which allowed to separate the paintings in at least, two groups. Essentially, the experiments point out the presence of hematite $\left(\mathrm{Fe}_{2} \mathrm{O}_{3}\right)$ as the common pigment among these groups. However, the 


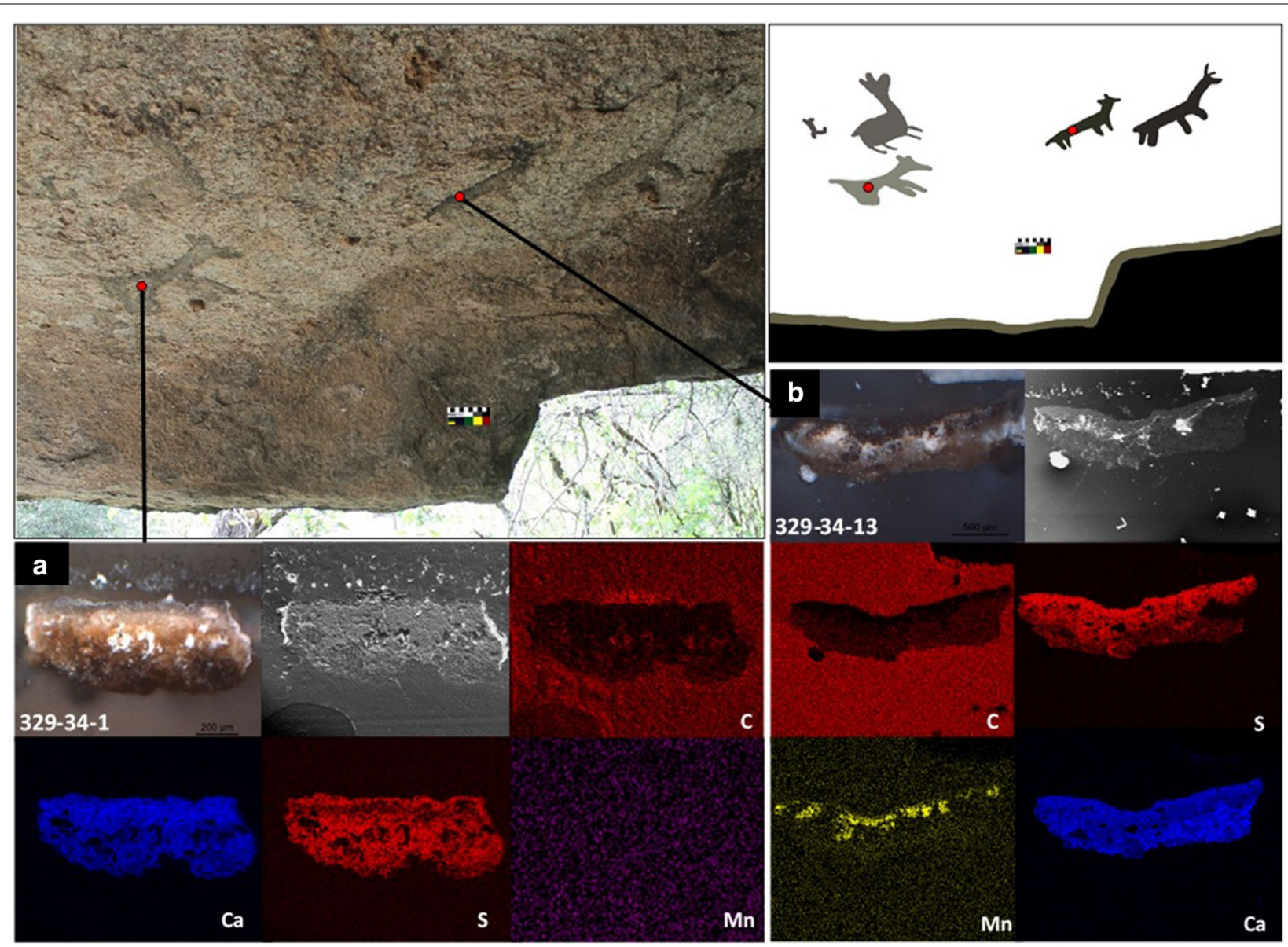

Fig. 3 SEM-EDS mapping analyses of black paintings at Oyola 34. a Elemental mappings of sample 329-34-1 and, b sample 329-34-13

differences lay on the absence or presence of additives. To this end, the samples from the first group (Fig. 7a) are composed by figures whose chemical composition contains gypsum and hematite. As indicated in Fig. 7a, hematite was attributed by its characteristic bands at 224, 293, 299, $409 \mathrm{~cm}^{-1}$ while gypsum by the band at $1007 \mathrm{~cm}^{-1}[12,55]$. The SEM-EDS mappings presented the corresponding concentrations of iron, sulfur and calcium in the painting layer. On the other hand, the second group, does not evidence calcium in the chemical mappings (Fig. 7b) discarding in this way, the presence of gypsum in the paint mixture.

Similarly, the thorough study of red paintings at Oyola 7 verified the behavior having red paintings containing homogeneous hematite/gypsum mixtures (Fig. 8b) and some of them have not (Fig. 8a). The selective presence of gypsum in some paintings could not be explained by differences in natural degradation processes because the figures studied are very close in the wall and most likely were exposed to similar degradation conditions over the time. These examples allowed us to highlight that, even when pigments are similar, it is possible to discriminate different paint mixtures of similar hues by the presence/ absence of additives. This fact can be interpreted as an intention of the rock art painter to achieve some aesthetical or technological purpose by mixing them.

\section{Physical differences between paintings mixtures}

The cave Oyola 1 gathers two groups of black paintings. The first one (Fig. 9a) is composed by anthropomorphic and zoomorphic figures painted with wider and darker edges, perhaps as a consequence of a digital execution. Among the zoomorphic designs, it is possible to discern some camelids and a feline. The other group, also painted in black, presents only zoomorphic figures of camelids and birds. This group has been done with thin strokes, possibly with a sharp instrument (Fig. 9b).

The chemical analysis of both groups evidenced the presence of carbon as the main pigment in the paint mixtures. However, under a closer study of the physical (morphological) characteristics of the micro-stratigraphies it is possible to distinguish, at least, two paint 


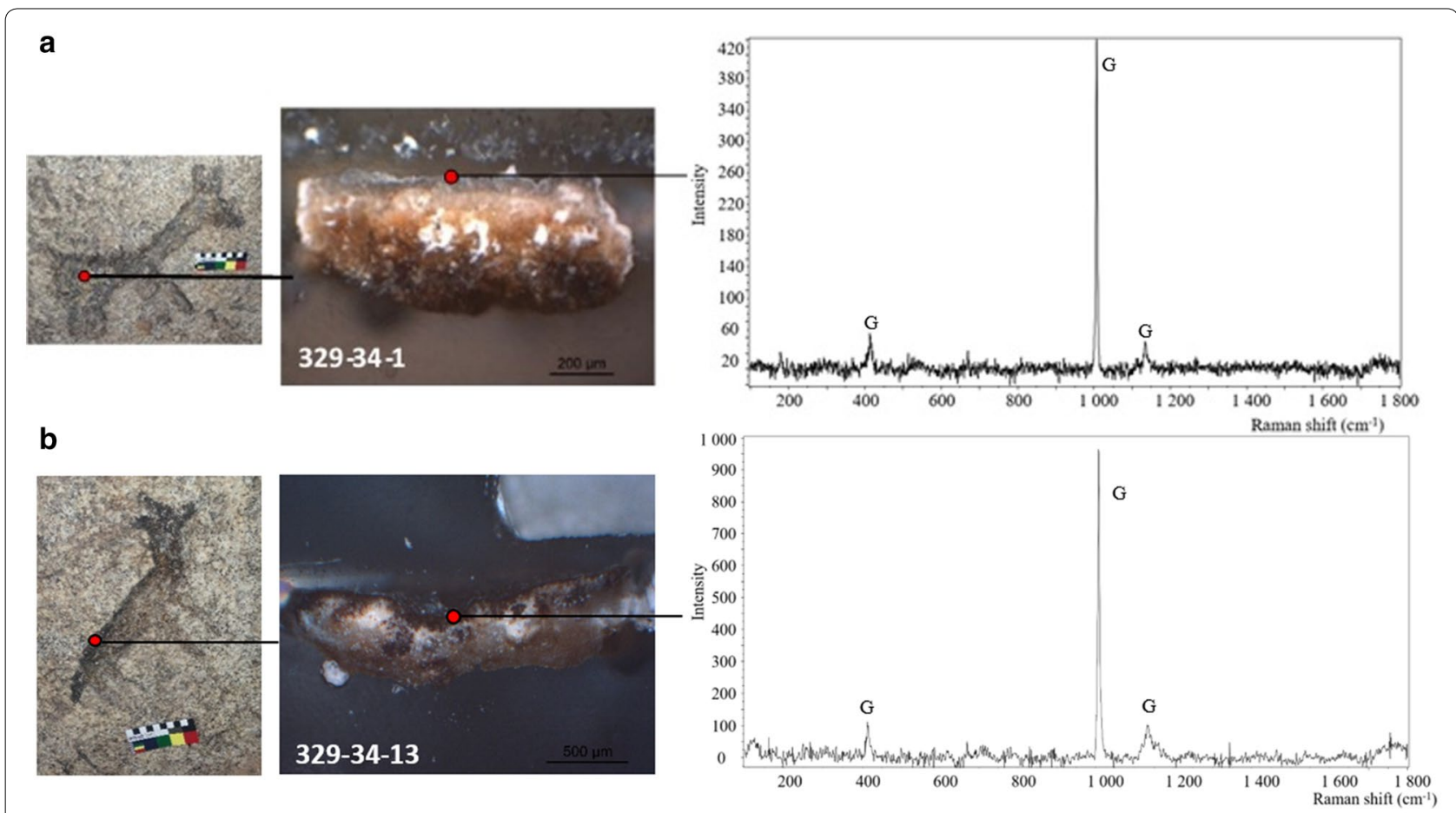

Fig. 4 mRS analyses of black paintings at Oyola 34 showing the bands of gypsum (G). a Raman spectrum from pictorial layer from sample 329-34-1 and, $\mathbf{b}$ from sample 329-34-13

mixtures. In this occasion, the difference does not lay on the chemical composition, but it is based on the morphological aspects. More specifically on the particle size which could be strongly related to grinding differences between paint mixtures. Taking into account that both motifs are from the same cave, these properties can occur either by the duration of the grinding process or by the use of different technological tools. As an example, the cross-section of sample 329-1-19 exhibits carbon particles whose average cross section areas are $31,8 \mu \mathrm{m}$ (s.d. $32,3 \mu \mathrm{m}, \mathrm{n}=29$ ) (Fig. 9b). In contrast the sample 329-117 , also executed with carbon, has a particle size smaller than the resolution of the optical microscope (Fig. 9a). Probably this smaller size is due to an intense grinding process. The measures of stratum thickness show differences between paintings, with an average of $109.5 \mu \mathrm{m}$ (s.d. $\pm 46 \mu \mathrm{m} \mathrm{n}=10$ ) in sample 329-1-19 and 26,2 $\mu \mathrm{m}$ (s.d. $\pm 5.92 \mu \mathrm{m} \mathrm{n}=19$ ) in sample 329-1-17.

\section{Discussion}

As we described, in spite of the uniformity that characterizes the rock art of Oyola's caves, a close understanding of the chemical and physical properties of paint mixtures bring us the possibility to discern differences in the materials selected and how they were processed and applied. In this sense, archaeometric studies stood out as a valuable tool to discriminate between different paint mixtures that could be linked with various painting events at the same cave, perhaps chronologically distanced. This point could be especially relevant to understand the history of archaeological sites as Oyola, where the rock art panels do not exhibit clear evidences of modifications in time (e.g. overlappings, different styles, etc.). In this line, these methodological tools were capable to rewrite the understanding of panels that have been interpreted as the uniform product of one society, period or culture. Therefore, as one of the main results of our work, it is relevant to note that even the most homogeneous rock art panel could be the consequence of more than one paint mixture and, perhaps, different painting events.

As exposed above, notwithstanding their similar morphologies, the figures at Oyola 34 have been painted with different black pigments, in some cases manganese oxides and probably carbon-based pigments in the others. However, this diversity could not be understood as an exception but as characteristic of other caves at the site. For instance, Oyola 7, where the use of different white pigments to produce similar paintings was detected. In other cases, it has been discovered the use of additives or charges (as gypsum) only in some paintings, which implies different paint mixtures and, consequently, different painting events. Despite we have 


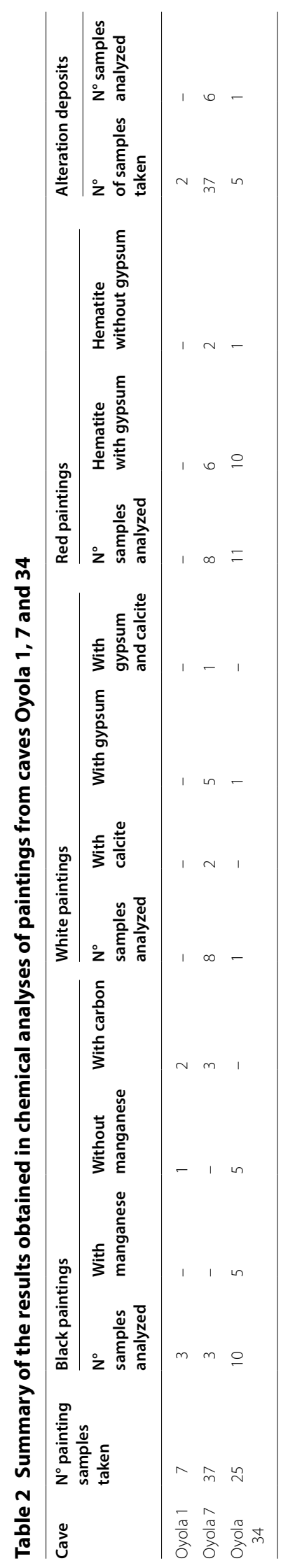




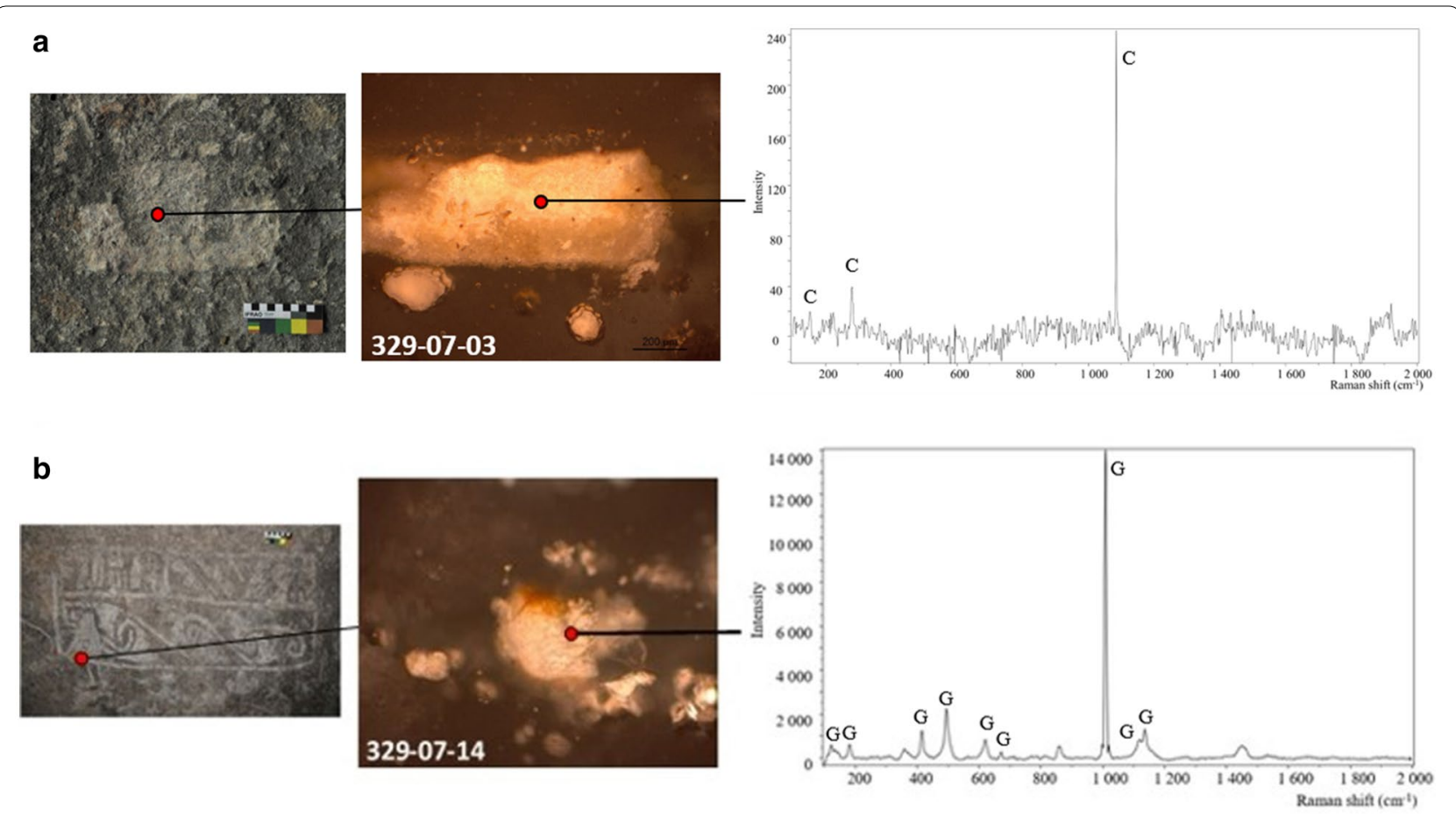

Fig. 5 mRS analyses of white paintings at Oyola 7. a Sample number 329-07-03 showing the bands of calcite (C); b sample number 329-07-14 showing the bands of gypsum (G)
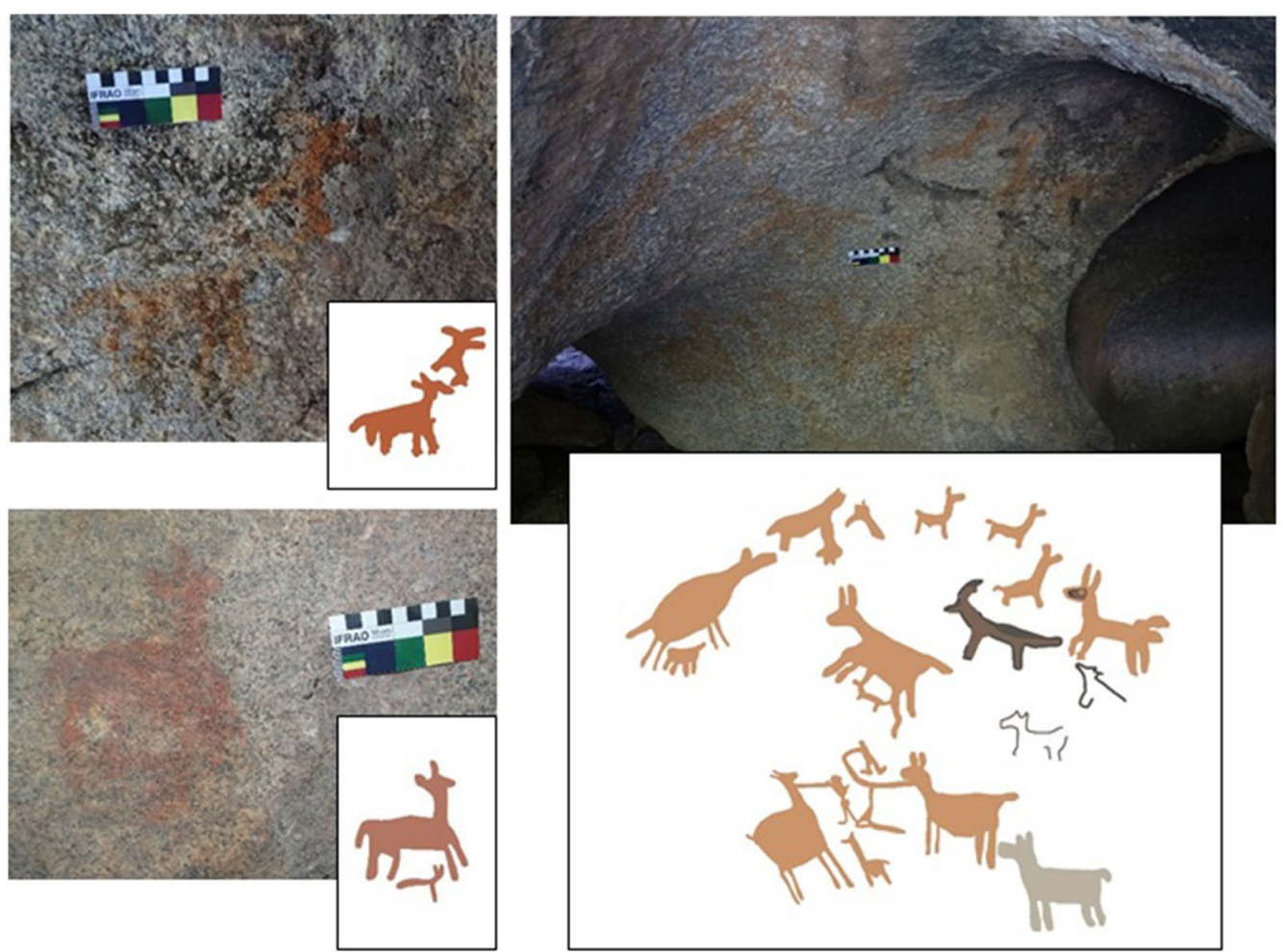

Fig. 6 Red paintings at Oyola 34 


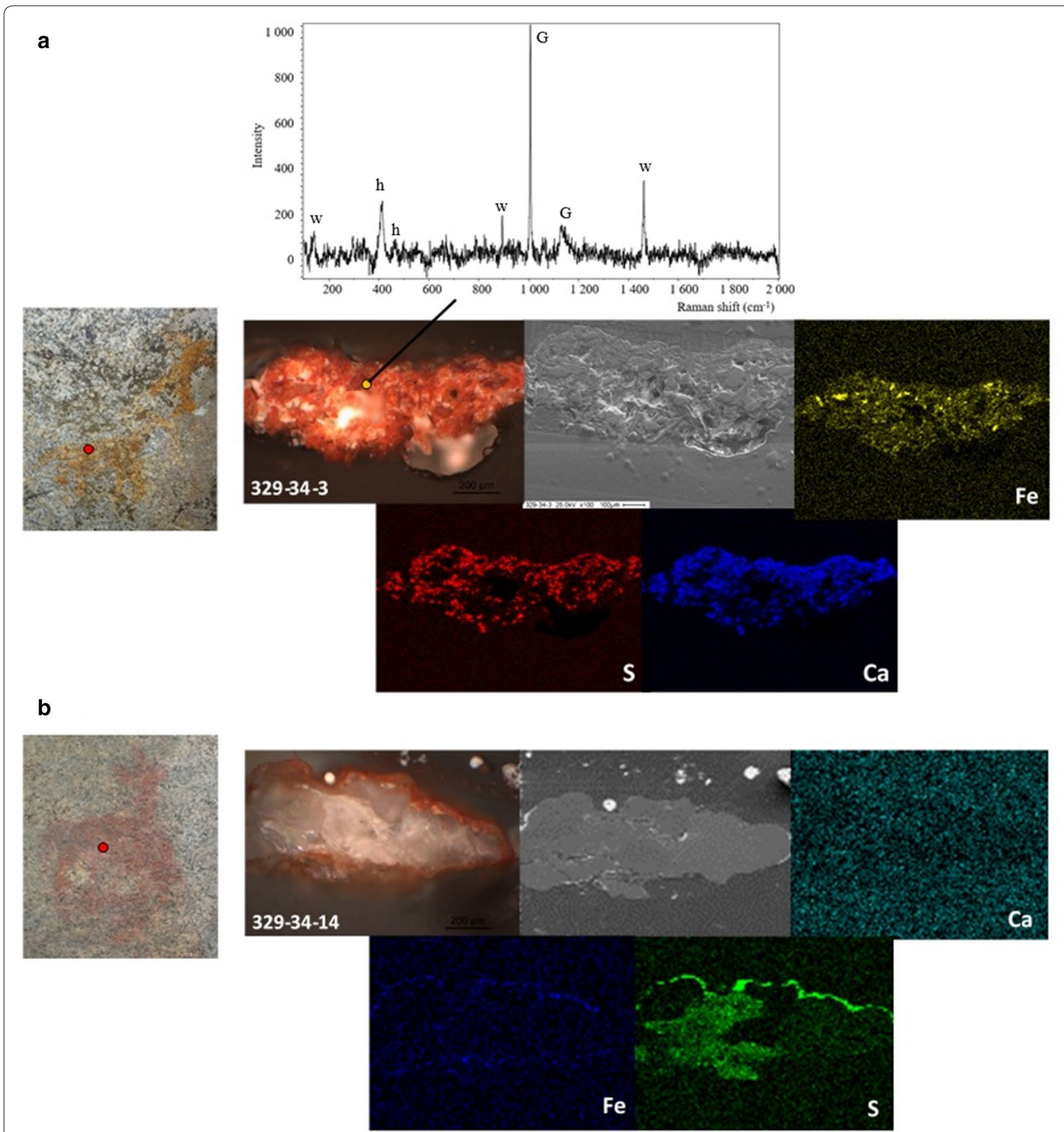

Fig. 7 Samples taken from Oyola 34. a Red sample (329-34-3) analyzed by mRS showing the bands of hematite (h), gypsum (G) and weddellite (w); and SEM-EDS elemental mapping. b Red sample (329-34-14) analyzed by SEM-EDS elemental mapping

scarce information about the organic components of paintings, we could hypothesize that this matter might be another source of paint diversity focused on binders. Finally, when the chemical compositions of paintings are similar, physical differences in pigment preparation such as particle size and stratum thickness can emerge as an alternative strategy. As we present in the case of Oyola 1, black painting done with the same pigment (carbon) could be manufactured using a diversity of technical processes, which will give different morphological properties such as particle size and stratum thickness $[57,58]$. 

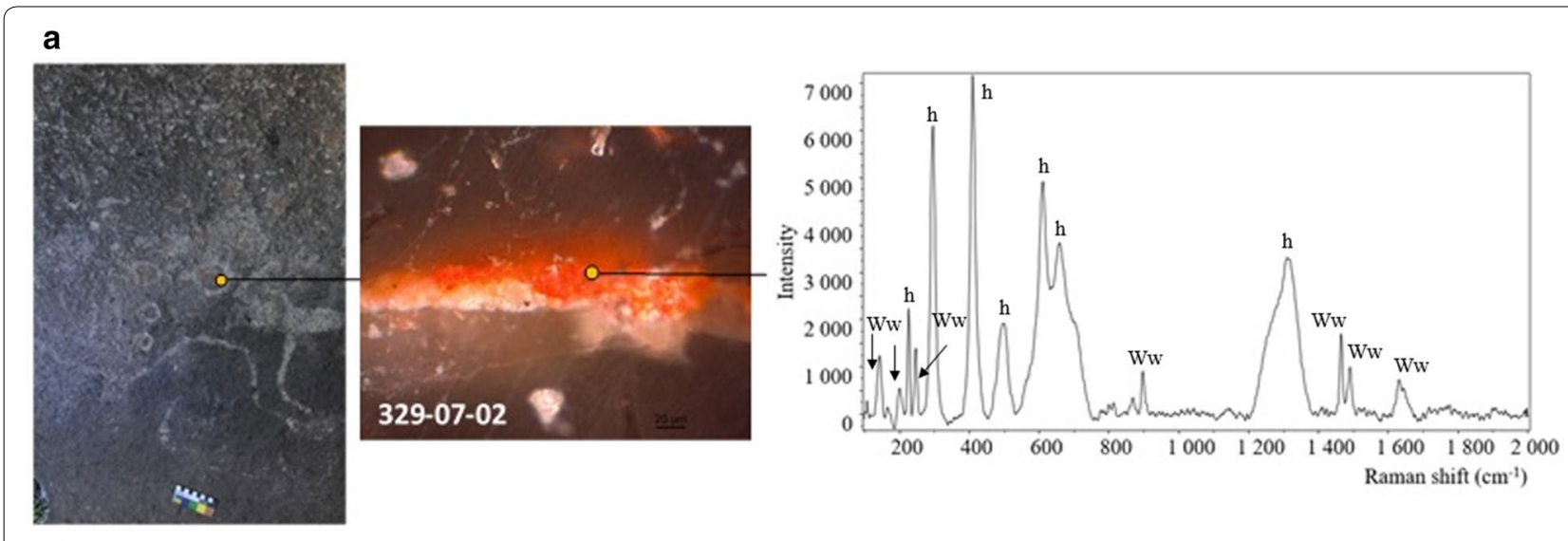

b
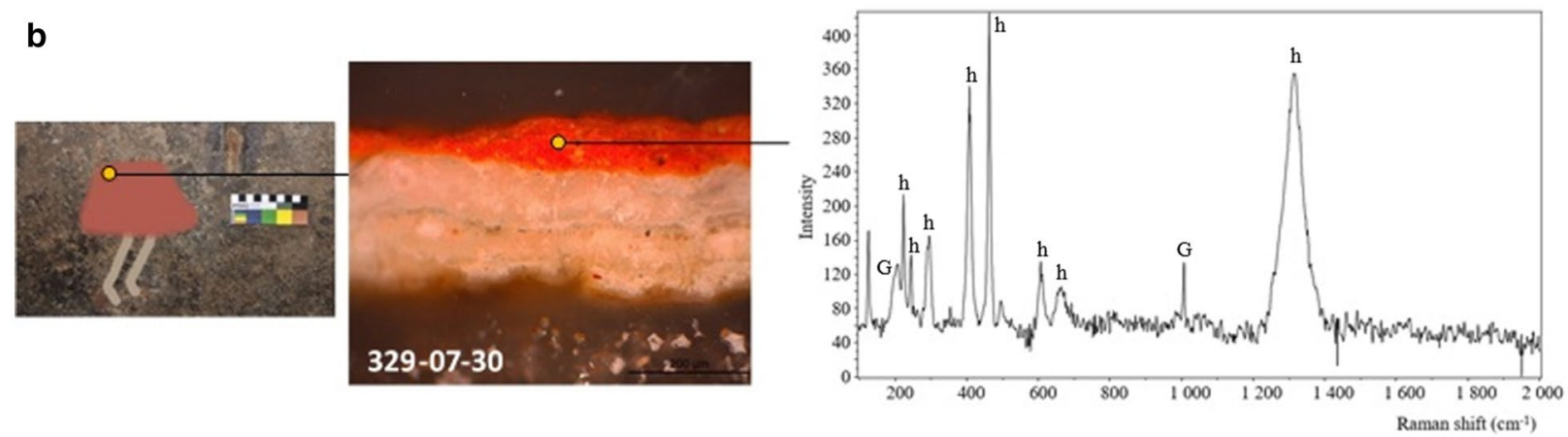

Fig. 8 mRS results of white samples from Oyola 7. a Sample 329-07-02 showing the bands of hematite (h) and gypsum (G) and, b sample 329-07-30 showing the bands of hematite (h)

A second point in this discussion is about the possibilities that the physicochemical differences gave us to identified between paint mixtures in order to understand the ancient painting techniques. These analyses could allow us to discern some aspects about the whole process of painting production, from obtaining the raw materials to the final figure, showing the different steps, elections and actors involved in the process. To the best of our knowledge, except for some valuable works [29, 59-61], the use of archaeometric studies to explore similar topics have been more exploited in other disciplines different to archaeology, such as art history and heritage science [56, 62-64]. Moreover, new concepts based on technical art studies can be incorporated by the archaeometry field to reinterpret the technical execution of rock art. In this line, archaeological physicochemical studies usually have less information about technical execution but a summary of the materials employed. Besides, we thought that the identification of material recurrences as well as the execution features of rock paintings could allow us to discriminate between the variety of painting techniques used at particular sites and regions. Moreover, this piece of information will enable us to highlight the active role of the painters and the complexity of these processes.
With a limited variety of raw materials available; classical picture of the ancient cultures exhibits people doing the same paint mixtures with similar components worldwide (e.g. iron oxides for reds, carbon for blacks, gypsum and calcite for whites). In this work, we proposed a richer vision, where the selections of materials and execution techniques are not trivial.

\section{Conclusions}

The research of the history of production, transformation and uses of rock painting is a problem that occupies researchers widely. This problem is particularly relevant in the study of archaeological sites where rock art panels have similar colors, shapes and sizes are interpreted as the expression of a single painting event, in many cases attributed to particular cultures, styles or periods. As it was described, a closer archaeometric examination of the Oyola's caves exposed enough results to differentiate paint mixtures and reach a more complex image of the overall painting process of the site. The analysis of micro-stratigraphic samples by SEM-EDS and Raman has proven to be a good starting point to characterize the inorganic components of each layer. Other micro-spectroscopic (micro- Fourier transform infrared 

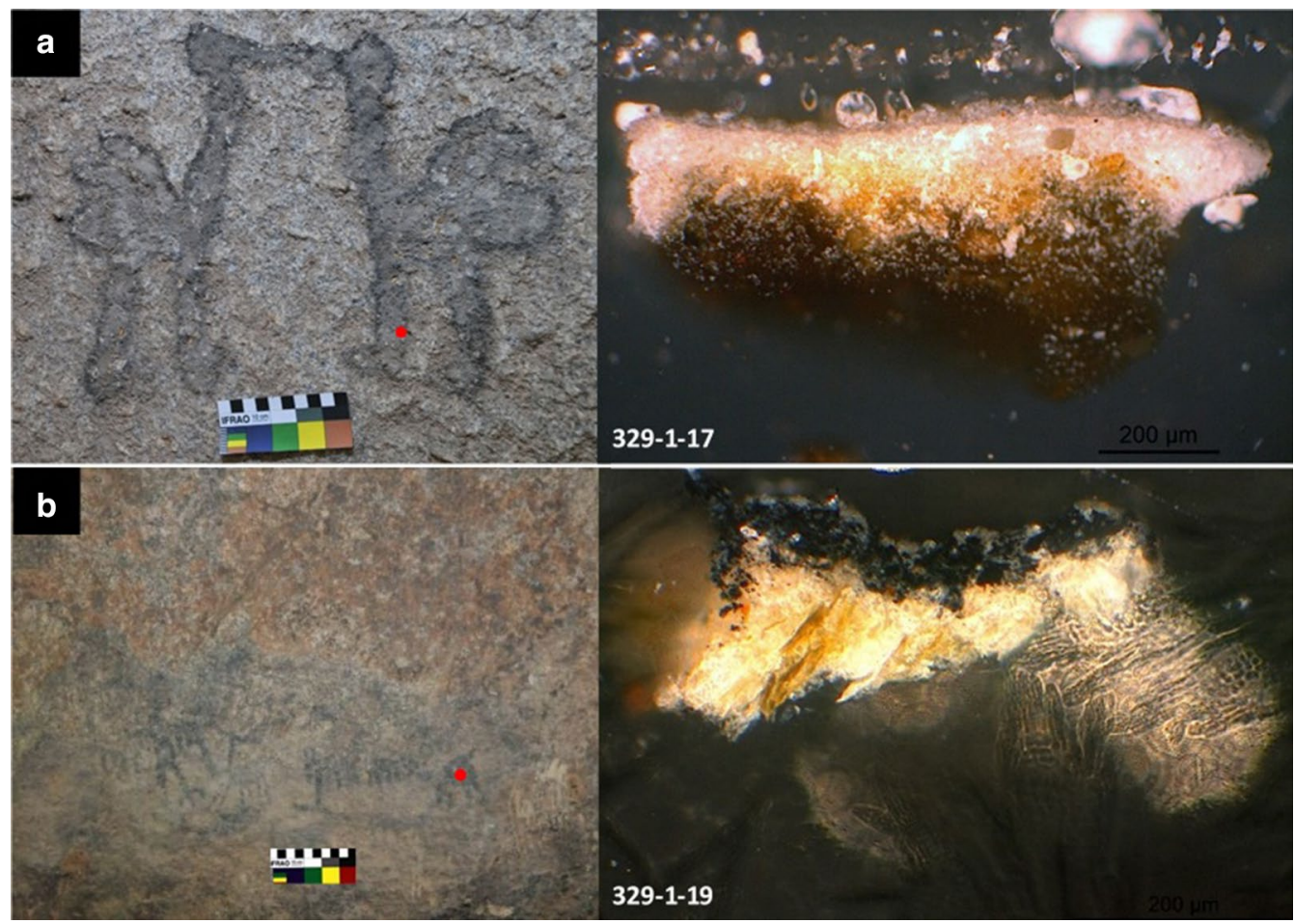

Fig. 9 Black paintings taken from Oyola 1

spectroscopy) or bulk (Gas chromatography-mass spectrometry) techniques to inquire into the organic materials are strongly recommended. In this line, other methodological and technical approaches $[18,27]$ could help us to connect these diversity of paint mixtures with different lines of archaeological evidence and give them a chronological frame.

In the same way, the archaeometric research could be a good strategy to explore the painting techniques used in the past. This approach transcends the traditional chemical characterization of rock paintings used in archaeology, usually linked with the identification of the main pigments, and allows us to identify particular forms to combine materials with technical actions in order to produce paints with special characteristics as durability, adherence, brightness, contrast, etc. This insight into the painting techniques could be a valuable way to highlight the active role of past painters, whose practices connected the structural rules with the historical contingencies and the individual agencies producing different paint mixtures through time. New lines of experimental essays conducted to replicate antique paintings could be a good complement to validate these physicochemical analyses and aid as another line of evidence to understand the past painting techniques.
Finally, the understanding of the involved materials and historical processes are crucial for the future design of personalized conservation and restoration strategies.

\section{Abbreviations}

mRS: Micro-Raman spectroscopy; SEM-EDS: Scanning electron microscopy with energy dispersive $X$-ray.

\section{Acknowledgements}

The group of authors is grateful with Soledad Pereda from Instituto Nacional de Tecnología Industrial (Buenos Aires, Argentina) for the SEM-EDS studies and with Comisión Nacional de Energía Atómica (Buenos Aires, Argentina) for Raman analyses. The group is also thankful to Noemi Mastrangelo for some of the sample inclusion and cross-section preparation. This article could not be possible without the collaboration of all members of the El Alto-Ancasti's research teams from Catamarca, Buenos Aires and Córdoba.

\section{Authors' contributions}

LG: coordinator of the manuscript. Sampling. Evaluation of results. EAE: sampling at Oyola 34, inclusion of cross-sections and collection of SEM-EDS data. Figures and tables. FM, MQ: coordinators of the archaeological project. FM, LG: collection of Raman data. LG, MT: data interpretation and drafted the manuscript. EAE, FM, MQ: gave valuable input and comments. All authors read and approved the final manuscript.

\section{Funding}

The Agencia Nacional de Promoción Científica y Tecnológica (Argentina) funded the archaeological project (PICT 2017-2462; PICT 2017-2589). Also, the Instituto de Investigaciones sobre el Patrimonio Cultural (UNSAM), Escuela de Arqueología (UNCA) and Centro de Investigaciones y Transferencia Catamarca (CONICET, UNCA) and CONICET made possible all the research. 


\section{Availability of data and materials}

The datasets analyzed during the current study are available from the corresponding author on reasonable request.

\section{Competing interests}

The authors declare that they have no competing interests.

\section{Author details}

${ }^{1}$ Instituto de Investigaciones Sobre el Patrimonio Cultural (IIPC-TAREA), Universidad Nacional de San Martín, Benito Quinquela Martín 1784, Buenos Aires, Argentina. ${ }^{2}$ Centro de Investigaciones y Transferencia Catamarca (CONICETUNCa), Prado 366, S. F. V., de Catamarca, Argentina. ${ }^{3}$ Instituto de Investigación e Ingeniería Ambiental (3iA), Universidad Nacional de San Martín (UNSAM), San Martín, Buenos Aires, Argentina. ${ }^{4}$ Escuela de Arqueología, Universidad Nacional de Catamarca, Av. Belgrano 300, S. F.V., de Catamarca, Argentina.

Received: 3 April 2020 Accepted: 19 June 2020

Published online: 24 June 2020

\section{References}

1. Huntley J, Aubert M, Ross J, Brand HEA, Morwood MJ. One colour (at least) two minerals: a study of mulberry rock art pigment and a mulberry pigment "quarry" from the Kimberley, northern Australia. Archaeometry. 2015;57:77-99.

2. Lofrumento C, Ricci M, Bachechi L, Feo D, Castellucci EM. The first spectroscopic analysis of Ethiopian prehistoric rock painting. J Raman Spectrosc. 2012;43:809-16. https://doi.org/10.1002/jrs.3096.

3. Gomes H, Rosina P, Holakooei P, Solomon T, Vaccaro C. Identification of pigments used in rock art paintings in Gode Roriso-Ethiopia using Micro-Raman spectroscopy Identi fi cation of pigments used in rock art paintings in Gode Roriso-Ethiopia using Micro-Raman spectroscopy. J Archaeol Sci. 2013;40:4073-82. https://doi.org/10.1016/j.jas.2013.04.017.

4. Sepúlveda M, Gutierrez S, Carcamo J, Oyaneder A, Valenzuela D, Montt I, et al. In situ X-ray fluorescence analysis of rock art paintings along the coast and valleys of the Atacama Desert, Northern Chile. J Chil Chem Soc. 2015;60:2822-6.

5. Stuart BH, Thomas PS. Pigment characterisation in Australian rock art: a review of modern instrumental methods of analysis. Herit Sci. 2017;5:10

6. Chalmin E, Castets G, Delannoy J, David B, Barker B, Lamb L, et al. Geochemical analysis of the painted panels at the "Genyornis" rock art site. Quatern Int. 2017:430:60-80.

7. Edwards HGM, Newton EM, Russ J. Raman spectroscopic analysis of pigments and substrata in prehistoric rock art. J Mol Struct. 2000;550-551:245-56.

8. Russ J, Kaluarachchi WD, Drummond L, Edwards HGM. The nature of a whewellite-rich rock crust associated with pictographs in Southwestern Texas. Studies in Conservation. 1999;44:91. http://www.jstor.org/stabl e/1506721?origin=crossref.

9. Prieto B, Seaward MRD, Edwards HGM, Rivas T, Silva B. An Fourier transform-Raman spectroscopic study of gypsum neoformation by lichens growing on granitic rocks. Spectrochim Acta. 1998;55:211-7.

10. Sotiropoulou S, Sciutto G, Tenorio AL, Bonaduce I, Prati S, Mazzeo R, et al. Advanced analytical investigation on degradation markers in wall paintings. Microchem J. 2018;139:278-94. https://doi.org/10.1016/j.micro c.2018.03.007.

11. Vandevelde S, Brochier J, Petit C, Slimak L. Establishment of occupation chronicles in Grotte Mandrin using sooted concretions: rethinking the Middle to Upper Paleolithic transition gol e. J Hum Evol. 2017;112:70-8.

12. Tascon M, Mastrangelo N, Gheco L, Gastaldi M, Quesada M, Marte F. Micro-spectroscopic analysis of pigments and carbonization layers on prehispanic rock art at the Oyola's caves, Argentina, using a stratigraphic approach. Microchem J. 2016;129:297-304. https://doi.org/10.1016/j. microc.2016.07.003.

13. Bonneau A, Pearce D, Mitchell P, Staff R, Arthur C, Mallen L, et al. The earliest directly dated rock paintings from southern Africa: new AMS radiocarbon dates. Antiquity. 2017;91:322-33.

14. Troncoso A, Moya F, Sepúlveda M, Carcamo JJ. First absolute dating of Andean hunter-gatherer rock art paintings from North Central Chile. Archaeol Anthropol Sci. 2015. https://doi.org/10.1007/s12520-015-0282-z.
15. Bedford C, Robinson D, Perry J, Baker M, Miles J, Kotuola E, et al. Unravelling the Gordian knot: combining technologies to analyse rock Art in Pleito Cave. SCA proceedings. 2016;30:183-95.

16. Loubser J. Layer by layer: precision and accuracy in rock art recording and dating. In: Blundell G, Chippindale C, Smith B, editors. Seeing and knowing rock art with and without ethnography. Gauteng: Wits University Press; 1984. p. 149-67.

17. Russell T. The Application of the Harris Matrix to San Rock Art at Main Caves North, Kwazulu-Natal. The South African Archaeological Bulletin. 2000;55:60-70. http://www.jstor.org.gate3.inist.fr/stable/3888893\%5Cnht tp://www.jstor.org.gate3.inist.fr/stable/pdfplus/3888893.pdf.

18. Gheco L, Gastaldi M, Marte F, Quesada M, Tascon M, Mastrangelo N. About fires and paintings: three stratigraphic insights on the history of a cave with prehispanic rock art. J Archaeol Sci Rep. 2017;15:48-58.

19. David B, Delannoy J, Petchey F, Gunn R, Veth P, Genuite K, et al. Dating painting events through by-products of ochre processing: borologa 1 Dating painting events through by-products of ochre processing: Borologa 1 Rockshelter. Aust Archaeol. 2019;1:1-38. https://doi. org/10.1080/03122417.2019.1603263.

20. Moya Cañoles F. Variabilidad tecnológica en las pinturas rupestres de la cuenca hidrográfica del río Limarí. [Santiago de Chile]: Universidad de Chile; 2015.

21. Hernanz A, Gavira-Vallejo JM, Ruiz-López JF, Edwards HGM. A comprehensive micro-Raman spectroscopic study of prehistoric rock paintings from the Sierra de las Cuerdas, Cuenca, Spain. J Raman Spectrosc. 2008;39:972-84.

22. Gomes H, Collado H, Martins A, Nash GH, Rosina P, Vaccaro C, et al. Pigment in western Iberian schematic rock art: an analytical approach. Mediterran Archaeol Archaeomet. 2015;15:163-75.

23. Mauran G, Lebon M, Détroit F, Caron B, Nankela A, Pleurdeau D, et al. First in situ pXRF analyses of rock paintings in Erongo, Namibia: results, current limits, and prospects. Archaeol Anthropol Sci. 2019;39:573-7.

24. Mauran G, Bassel L, Ferrier C, Lacanette D, Bousquet B, Chapoulie R. Variability and sampling strategy of cave wall concretion: case study of the moonmilk found in Leye Cave (Dordogne). Archaeometry. 2018. https:// doi.org/10.1111/arcm.12434.

25. Bonneau A, Pearce DG, Pollard AM. A multi-technique characterization and provenance study of the pigments used in San rock art, South Africa. J Archaeol Sci. 2012;39:287-94. https://doi.org/10.1016/j.jas.2011.09.011.

26. Sepúlveda M. Pinturas rupestres y tecnología del color en el extremo sur de Chile. Magallania. 2011;39:193-210. https://doi.org/10.4067/S0718 $-22442011000100012$.

27. Gheco L, Gastaldi M, Mastrangelo N, Quesada M, Marte F, Tascon M. Entre humos, fuegos y pinturas. Una metodología para conectar historias sobre una cueva con arte rupestre del sitio de Oyola (Catamarca, Argentina). Boletín del Museo Chileno de Arte Precolombino. 2019;24:131-52.

28. Yacobaccio HD, Cata MP, Sola P, Alonso MS. Estudio arqueológico y fisicoquímico de pinturas rupestres en Hornillos 2 (Puna de Jujuy). Estudios atacameños. 2008;2:5-28. http://www.scielo.cl/scielo.php?scrip $\mathrm{t}=$ sci_arttext\&pid=S0718-10432008000200002\&lng=en\&nrm=iso\&tlng $=$ en.

29. Chalmin E, Menu M, Vignaud C. Analysis of rock art painting and technology of Palaeolithic painters. Meas Sci Technol. 2003;14:1590-7.

30. De La Fuente GA, Nazar DC. Pintores antiguos, tecnología y pigmentos: aportes para la reconstrucción de las cadenas operativas implicadas en la producción de las pinturas de La Tunita, Motegasta y La Resfalosa (Dptos. Ancasti y La Paz). Imágenes rupestres: lugares y regiones. Rosario; 2016.

31. Hedges REM, Ramsey CB, Klinken GJVAN, Nielsen C, Etchegoyen A, Niello JDF, et al. Methodological Issues in the 14C Dating of Rock Paintings. In: 16th International 14C Conference Radiocarbon. 1998;40:35-44.

32. Sepúlveda M, Valenzuela D, Cornejo L, Lienqueo H, Rousselière H. Óxidos de Manganeso en el Extremo Norte de Chile: Abastecimiento, Producción y Movilidad del Color Negro Durante el Periodo Arcaico. Chungara Revista de Antropología Chilena. 2013;45:143-60. http://www.chungara. clNols/2013/45-1/Sepulveda_et_al_45-1-2013.pdf.

33. Solá P, Yacobaccio H, Rosenbusch M, Maier M, Vázquez C, Catá MP. Hematita Vs. Arcillas : Su Potencial Como Pigmentos Rojos Y Su Uso En Tres Sitios De La Puna Jujeña (Argentina). Boletín del museo chileno de arte precolombino. 2013;18:67-83.

34. Vázquez C, Maier MS, Parera SD, Yacobaccio H, Solá P. Combining TXRF, FT-IR and GC-MS information for identification of inorganic and organic 
components in black pigments of rock art from Alero Hornillos 2 (Jujuy, Argentina). Anal Bioanal Chem. 2008;391:1381-7.

35. Livingston A, Robinson E, Armitage RA. Characterizing the binders in rock paintings by THM-GC-MS: La Casa de Las Golondrinas, Guatemala, a cautionary tale for radiocarbon dating. Int J Mass Spectrom. 2009;284:14251. https://doi.org/10.1016/j.jims.2008.12.008.

36. Chalmin E, Vignaud C, Menu M. Palaeolithic painting matter natural or heat-treated pigment? Appl Phys A. 2004;00:1-5.

37. Pomies M, Menu M. Red palaeolithic pigments: natural hematite or heated goethite? Archaeometry. 1999;41:275-85.

38. Aschero C. Pinturas rupestres, actividades y recursos naturales; un encuadre arqueológico. In: Yacobaccio H, Borrero LA, García L, Politis G, Aschero C, Bellelli C, editors. Arqueología contemporánea Argentina Actualidad y perspectivas. Buenos Aires: Ediciones Búsqueda; 1988. p. 109-42.

39. Fiore D. The economic side of rock art: concepts on the production of visual images. Rock Art Research. 2007;24:149-60.

40. Fiore D. The materiality of rock art: Image-making technology and economy viewed from Patagonia. In: Troncoso A, Armstrong F, Nash G, editors. Archaeologies of rock art: South American Perspectives. New York: Routledge; 2018. p. 23-57.

41. Gradin C. Algunos aspectos del análisis de las manifestaciones rupestres. Revista del Museo Provincial de Neuquén. Neuquén. 1978;1:120-33.

42. Gheco L, Tascon M, Gastaldi M, Ahets Etcheberry E, Pereda S, Mastrangelo N, et al. Hidden paintings, forgotten histories: a micro-stratigraphic approach to study coated rock art. Archaeological and Anthropological Sciences. 2019;11:5037-52.

43. Segura A. Pictografías de Catamarca. Separata de la Revista de la Junta de Estudios Históricos de Catamarca. 1971;1962-1968.

44. De la Fuente N, Nazar DC, Pelli E. Documentación y diagnóstico del arte rupestre de La Tunita, Provincia de Catamarca, República Argentina. In: La CO de la VM de la C de A y su D, editor. La Cultura de La Aguada y sus Expresiones Regionales. La Rioja: EUDELAR; 2005. p. 227-44.

45. Llamazares AM. Arte rupestre de la cueva de La Candelaria, Provincia de Catamarca. Publicaciones de Arqueología. 1999;50.

46. Gordillo I, Baldini M, Kusch F. Entre objetos, rocas y cuevas: significados y relaciones entre la iconografía rupestre y mobiliar de Aguada. In: Podestá MM, de Hoyos M, editors. Arte en las Rocas Arte Rupestre, Menhires y Piedras de Colores en Argentina. Buenos Aires: Sociedad Argentina de Antropología; 2000. p. 101-11.

47. González AR. Cultura La Aguada. Arqueología y diseños. Buenos Aires: Filmediciones Valero; 1998.

48. González AR. Arte precolombino de la Argentin. Buenos Aires: Filmediciones Valero; 1977.

49. Gramajo A, Martínez Moreno H. Otros Aportes al Arte Rupestre del Este Catamarqueño. Antiquitas. 1978;26:12-7.

50. Gramajo A, Martínez Moreno H. Otros aportes al arte rupestre del este catamarqueño. Estudio Museo arqueológico Emilio y Duncan Wagner. $1982 ; 3: 77-88$

51. Gastaldi M, Gheco L, Moreno E, Granizo G, Ahumada M, Egea D, et al. Primeros resultados de las excavaciones estratigráficas en Oyola 7 (Sierra de El Alto-Ancasti, provincia de Catamarca, Argentina). Comechingonia. 2016;20:73-104
52. Gheco L. El laberinto de las paredes pintadas. Una historia de los abrigos con arte rupestre de Oyola, Catamarca. Tesis Doctoral inédita: Universidad Nacional de Córdoba; 2017

53. Gheco L, Quesada M. El arte rupestre de Oyola (dpto. El Alto, Catamarca): un caso de narrativas superpuestas. Aportes científicos desde Humanidades (UNCa). 2012;9:228-44.

54. Gheco L, Poliszuk A. Caracterización química de pinturas rupestres prehispánicas del sitio arqueológico de Oyola mediante sem-eds, drx, ft-ir, frx y gc-ms (Catamarca, Argentina). In: Pifferetti AA, Dosztal I, editors. Arqueometría argentina, metodologías cientíicas aplicadas al estudio de los bienes culturales: datación, caracterización, prospección y conservación. Buenos Aires: Aspha; 2015. p. 271-84.

55. Burgio L, Clark RJH. Library of FT-Raman spectra of pigments, minerals, pigment media and varnishes, and supplement to existing library of Raman spectra of pigments with visible excitation. Spectrochim Acta. 2001;:57:1491-521.

56. Castellá F, Pérez-Estebanez M, Mazurek J, Monkes P, Learner T, Niello JF, et al. A multi-analytical approach for the characterization of modern white paints used for Argentine concrete art paintings during 1940-1960. Talanta. 2019:120:472.

57. Marte F, Mastrangelo N, Tascon M. The art of measuring: optical microscopy applied to the measurement of transversal sections. Eadem Utraque Europa. 2011;13:257-68.

58. Marte F, Tascón M, Mastrangelo N. The art of measuring Il: challenges in measuring particles in cross-sections. Eadem Utraque Europa. 2013;14:245-54.

59. López-Montalvo E, Roldán C, Badal E, Murcia-Mascarós S, Villaverde V. Identification of plant cells in black pigments of prehistoric Spanish Levantine rock art by means of a multi-Analytical approach. A new method for social identity materialization using chaõ Ãne opeÂratoire. PLoS ONE. 2017;12:1-27.

60. Chalmin E, Vignaud C, Farges F, Menu M. Heating effect on manganese oxihydroxides used as black Palaeolithic pigment. Phase Transitions. 2008;81:179-203

61. d'Errico F, Dayet Bouillot L, García-Diez M, Pitarch Martí A, Garrido Pimentel D, Zilhão J. The technology of the earliest European cave paintings: El Castillo Cave, Spain. J Archaeol Sci. 2016;70:48-65.

62. Magon PM, Del Lama EA. Material characterization, stratigraphy, textures, and painting techniques of the mural painting The Allegory of the Industrial Development of São Paulo by Fulvio Pennacchi. Stud Conserv. 2019. https://doi.org/10.1080/00393630.2018.1564502.

63. Vandivere A, van Loon A, Dooley KA, Haswell R, Erdmann RG, Leonhardt E, et al. Revealing the painterly technique beneath the surface of Vermeer's Girl with a Pearl Earring using macro- and microscale imaging. Herit Sci. 2019;7:1-16. https://doi.org/10.1186/s40494-019-0308-4.

64. Moretti P, Gallegos D, Marte F, Brunetti B, Sgamellotti A, Miliani C. Materials and techniques of twentieth century argentinean murals. Proc Chem. 2013;8:221-30. https://doi.org/10.1016/j.proche.2013.03.028.

\section{Publisher's Note}

Springer Nature remains neutral with regard to jurisdictional claims in published maps and institutional affiliations. 